\title{
A Collaborative Effort to Develop a Research Center in Engineering and Technology in Uganda
}

\author{
Frank T. Duda, Jr., Douglas K. Lauffer \\ Dept. of Electrical and Computer Engineering, Grove City College, Grove \\ City, PA 16127 / Dept. of Computer Information Systems and \\ Telecommunications, Community College Beaver County, Monaca, PA
}

\begin{abstract}
In order for Uganda Christian University (UCU) Mukono, Uganda to realize its vision of training East African students to be at the forefront of the impact of technology in both a cultural and a societal sense, a committee was formed to consider how this could be accomplished. The committee was made up of an interdisciplinary team of social scientists, religion professors and engineering educators familiar with the British, European, American and Australian models of engineering education. Surveys were conducted to gauge the needs and expectations of Ugandan industries as well as to assess the quality of student preparation and developmental needs. This paper discusses the development of a research center in engineering and technology at UCU and the supportive program infrastructure. The originality of our ideas comes from our participation with educators in Uganda and the mutual recognition of the need to develop more education in science and engineering.

Introduction
\end{abstract}

This paper presents a performance process model for implementing an engineering curriculum for the Uganda Christian University. Engineering education is non existent at the Uganda Christian University. This is a university that serves the educational needs of the Church of Uganda and admits any qualified student in Uganda or students of other countries. The Church of Uganda has about 5 million members which is approximately 20 per cent of the 24.7 million population of Uganda $^{1}$. The results of a survey conducted over a four year period show that there is both a need to train scientists and engineers as well as a need to train teachers at the secondary level to teach the basics of science and engineering. The findings were similar to the findings from other field work ${ }^{2}$. A curriculum leading to a Bachelor of Science degree in basic engineering fundamentals has been proposed to meet both of these needs.

The proposed program would include a core curriculum taken by both the students who plan to be science teachers at the secondary level as well as those who plan to complete the engineering degree. Initially, the secondary teachers who teach in both the public schools and private schools will be targeted for science/engineering post secondary training.

Proceedings of the 2003 American Society for Engineering Education Annual Conference \& Exposition Copyright (C) 2003, American Society for Engineering Education 
While they are completing the initial two years of course work at Uganda Christian University in the science/engineering fundamentals, they will also be called upon to recommend modifications in the proposed curriculum to ensure that the future students will receive adequate preparation. As these secondary education teachers become trained in science/engineering fundamentals, it is expected that the secondary students of the future will be adequately trained in the fundamentals so that they could complete the engineering degree.

\section{Underlying Assumptions}

Informal surveys were conducted over the past four years. These surveys had underlying assumptions, in that they would show obvious results, such as the need for technical assistance, financial aid and education. This is made clear by past research done by others ${ }^{3,4,5}$. However, because of the differences in culture, we needed to ask the questions, hear the answers and develop potentially helpful projects around the answers.

Survey Methodology

The surveys were done on an informal basis built around three questions and 150 to 200 leaders. The methodology for the survey was to meet with the leaders and informally ask the three questions and then to record the responses. The questions and answers were further support for our belief in the basis for a successful new research center model.

This study used qualitative research methods, in particular in-depth interviews, focus group discussions and a variety of Participatory Rapid Appraisal techniques ${ }^{6}$ with leaders, students and parents. A heuristic approach to the survey was used since the answers to the question were anticipated. The three survey questions were asked in the context of development in the country of Uganda. The following questions were asked of 150 to 200 leaders: What do you need? How do you deal with the unmet need(s)? What can we do to help in this process? The researchers held discussions with the stakeholders who comprise religious, community (hospital administration, business owners) and university leaders (professors/administrators). The geographic scope included a wide variety of settings, both urban (including universities) and rural in Kampala, Mukono, and the district of Bunyoro-Kitara.

\section{Our Current Work}

Over the last 4 years we have been working closely with a group of people who have a 10 year commitment to doing projects in the Church of Uganda Diocese of Bunyoro-Kitara, District of Bunyoro-Kitara, Uganda, Africa ${ }^{7}$. This work has been undertaken with the support of the local leadership and with acceptance and recognition of the federal government of Uganda. These projects are built around 7 initiatives:

1. Developing a coffee plantation

2. Eradicating malaria in the diocese

3. Developing medical dispensaries with basic laboratories

4. Education analysis and microcomputer training

Proceedings of the 2003 American Society for Engineering Education Annual Conference \& Exposition Copyright (C) 2003, American Society for Engineering Education 
5. Micro-enterprise business training

6. Telecommunications

7. Advanced training of ministers and their wives

8. Ox plowing

The Current Results

We are in our fifth year for these initiatives. There is now a coffee plantation that is yielding many pounds of coffee. There have been over 10,000 mosquito nets distributed, 1,000s of meters of screening material, and mosquito repellent with training on how to install and use them. There is a formerly abandoned dispensary which is reopening with local leadership managing it. There is a computer center with African trainers and there is access to the Internet. There have been several business development classes with courses in fundamental accounting and business planning by which people can determine how to start a business and the associated risks. An experimental wireless data communications system was implemented for communications with the coffee plantation. Several hundred pastors, spouses, and leaders have taken advanced pastoral training in areas in which they expressed interest such as family development, communications, research methods etc. An ox plowing project was implemented through African leaders (ox plowing was previously thought to be taboo). Many acres of land that were formerly plowed by hand are now done with assistance and economy of teams of oxen.

The Problem

During our time of working in Uganda we have recognized that there are not enough people educated in basic science and engineering to sustain or build basic infrastructures.

Our surveys among the leadership show that while they desire better systems for health, agriculture, water, electricity and communications, they need the education to support this. These findings compare with development initiatives and strategies in Uganda ${ }^{8,9}$. Currently at Uganda Christian University there are very good degree programs in liberal arts; there are none in engineering and science. As a result of our work and survey, the university desires to develop a curriculum in engineering and science.

\section{A Solution}

Since not only is there a need for scientist and engineers, there is also a need for teachers at the secondary level for teaching the basics of these subjects. We are therefore proposing an educational curriculum for working on both of these problems. We propose a four year plan of education in science and basic engineering to be offered through Uganda Christian University.

First, provide the basic education for science and engineering at the university while at the same time providing education support to teachers in the Bunyoro-Kitara District. Also, the university level training can be a feeder to support the teacher's education degree already at the university. By providing more science education there, teachers will have the training necessary for

Proceedings of the 2003 American Society for Engineering Education Annual Conference \& Exposition Copyright (C) 2003, American Society for Engineering Education 
developing students in science. These teachers can go back to Bunyoro-Kitara and teach secondary school students the math and basic science needed to go into a post secondary program in science / engineering. It must also be said that the science and engineering training is also a way for people to receive the fundamental basis for studying the medical field such as nursing.

\section{The Curriculum}

These objectives can be accomplished by developing a curriculum for engineering and science at the university. The proposed draft for the curriculum is found below. An important part of the program will give the students the opportunity to do field work. While important in any curriculum, the field work is particularly encouraged by national leaders and technical leaders in Uganda $^{10,11}$.

\begin{tabular}{|c|l||}
\hline $\begin{array}{c}\text { First Year } \\
\text { First Semester }\end{array}$ & $\begin{array}{l}\text { Fundamentals of Engineering/Scientific Mathematics } \\
\text { Technical Writing for Engineering and Science } \\
\text { Introduction to Chemistry }\end{array}$ \\
\hline $\begin{array}{c}\text { First Year Second } \\
\text { Semester }\end{array}$ & $\begin{array}{l}\text { Geometry I } \\
\text { Organic Chemistry I } \\
\text { Historical Perspective of Engineering and Science }\end{array}$ \\
\hline $\begin{array}{c}\text { Second Year } \\
\text { First Semester }\end{array}$ & $\begin{array}{l}\text { Geometry II } \\
\text { Organic Chemistry II } \\
\text { Fundamentals of Field Research }\end{array}$ \\
\hline $\begin{array}{c}\text { Second Year } \\
\text { Second Semester }\end{array}$ & $\begin{array}{l}\text { Mathematics for Engineers and Scientists } \\
\text { Structural Engineering and Science I } \\
\text { Intermediate Field Research Methods }\end{array}$ \\
\hline \hline Practicum I & $\begin{array}{l}\text { Approved degree candidates do a field practicum in an accepted area } \\
\text { of interest. }\end{array}$ \\
\hline \hline First Semester & $\begin{array}{l}\text { Engineering and Science Problems I } \\
\text { Electrical Engineering and Science I } \\
\text { Chemical Engineering and Science I } \\
\text { Applications in Engineering and Science }\end{array}$ \\
\hline $\begin{array}{c}\text { Third Year } \\
\text { Second Semester }\end{array}$ & $\begin{array}{l}\text { Engineering and Science Problems II } \\
\text { Electrical Engineering and Science II } \\
\text { Chemical Engineering and Science II }\end{array}$ \\
\hline \hline Practicum II & $\begin{array}{l}\text { Approved Degree Candidates do a field practicum in an accepted area } \\
\text { of interest. }\end{array}$ \\
\hline $\begin{array}{c}\text { Fourth Year } \\
\text { First Semester }\end{array}$ & $\begin{array}{l}\text { Engineering and Scientific Analysis } \\
\text { Electrical Engineering and Science III } \\
\text { Chemical Engineering and Science III }\end{array}$ \\
\hline \hline Second Semester & $\begin{array}{l}\text { Engineering and Science Leadership Trends } \\
\text { Proposal Writing in Engineering and Science } \\
\text { Application and Analysis Using Engineering and Science }\end{array}$ \\
\hline \hline
\end{tabular}

Proceedings of the 2003 American Society for Engineering Education Annual Conference \& Exposition Copyright $\left({ }_{0}\right.$ 2003, American Society for Engineering Education 
The choice of classes is based on current work in the country of Uganda. Also, the curriculum is related to the projects with which we are involved. It is necessary to have classes that will be relevant to the needs of the country and the opportunities there. The engineering/science will be integrated with existing liberal arts courses. This will provide a rich academic experience for the students $^{12}$

\section{The Technical Education Project}

The frame work of our project, in many ways, is open ended. By open, we do not mean to imply that there is not structure. On the contrary, we are able to measure the project progress using project management tools such as time tables for meeting objectives and milestones. With the benefit of project management tools, we will be able to evaluate the progress of each step in the process ${ }^{13}$.

This openness allows us to be flexible enough to incorporate dynamic and beneficial improvements. What we anticipate are new interests by stakeholders and additional contributors to the work as well as new stakeholders and participants. This openness is necessary for sustainability.

Also, there will be continued improvements in each step of the project. We recognize that a developing educational process and program needs changes along the way. The following is an example of a table with objectives and milestones for achieving and implementing a curriculum. By using a management tool for establishing objectives and goals, we will be able to clarify and measure progress. Please note these are examples.

\begin{tabular}{||l|l||}
\hline Winter/Spring 2003 & Texts/Materials prepared for shipping to Uganda \\
\hline \hline Summer 2003 & $\begin{array}{l}\text { Faculty selected in Secondary Schools for science assistance through } \\
\text { texts/laboratory materials. Uganda Christian University develops/selects } \\
\text { two basic courses }\end{array}$ \\
\hline Fall 2003 & $\begin{array}{l}\text { Student exit interviews and development of teacher surveys. } \\
\text { Revise curriculum, plan two more courses for the university. } \\
\text { Curriculum for developing standards (including technology) generated } \\
\text { by the Ugandan secondary and college teachers. }\end{array}$ \\
\hline $\begin{array}{l}\text { Winter } \\
2003-2004\end{array}$ & Curriculum revised, secure materials for laboratories and texts. \\
\hline Spring 2004 & Evaluate/survey student progress and teacher satisfaction \\
\hline Fall 2004 & $\begin{array}{l}\text { Curriculum revised based on student progress and faculty } \\
\text { needs. Add two more courses at the university. Apply for grants } \\
\text { for the university and secondary teachers work. } \\
\text { Survey re-administered to students/teachers. }\end{array}$ \\
\hline Winter 2005 & $\begin{array}{l}\text { Student teaching syllabus revised to reflect increased interest in student } \\
\text { teaching (focus of science). }\end{array}$ \\
\hline \hline
\end{tabular}

Proceedings of the 2003 American Society for Engineering Education Annual Conference \& Exposition Copyright $\left({ }^{\circ}\right.$ 2003, American Society for Engineering Education 


\begin{tabular}{|l||l||}
\hline $\begin{array}{l}\text { Spring/Summer } \\
2005\end{array}$ & $\begin{array}{l}\text { Use university interns in engineering/science projects (coffee plantation, } \\
\text { dispensaries, telecommunications, computers etc.). }\end{array}$ \\
\hline Fall 2006 & $\begin{array}{l}\text { Add courses to the university curriculum for a degree for BS in } \\
\text { Engineering Fundamentals. }\end{array}$ \\
\hline Spring 2006 & Graduate Engineering/Science Degree Candidates \\
\hline
\end{tabular}

\section{Process Flow Model}

The model below illustrates what the project will do and what are some anticipated, sustainable, results. The results imply the performance of the educational project which includes the proposed curriculum.

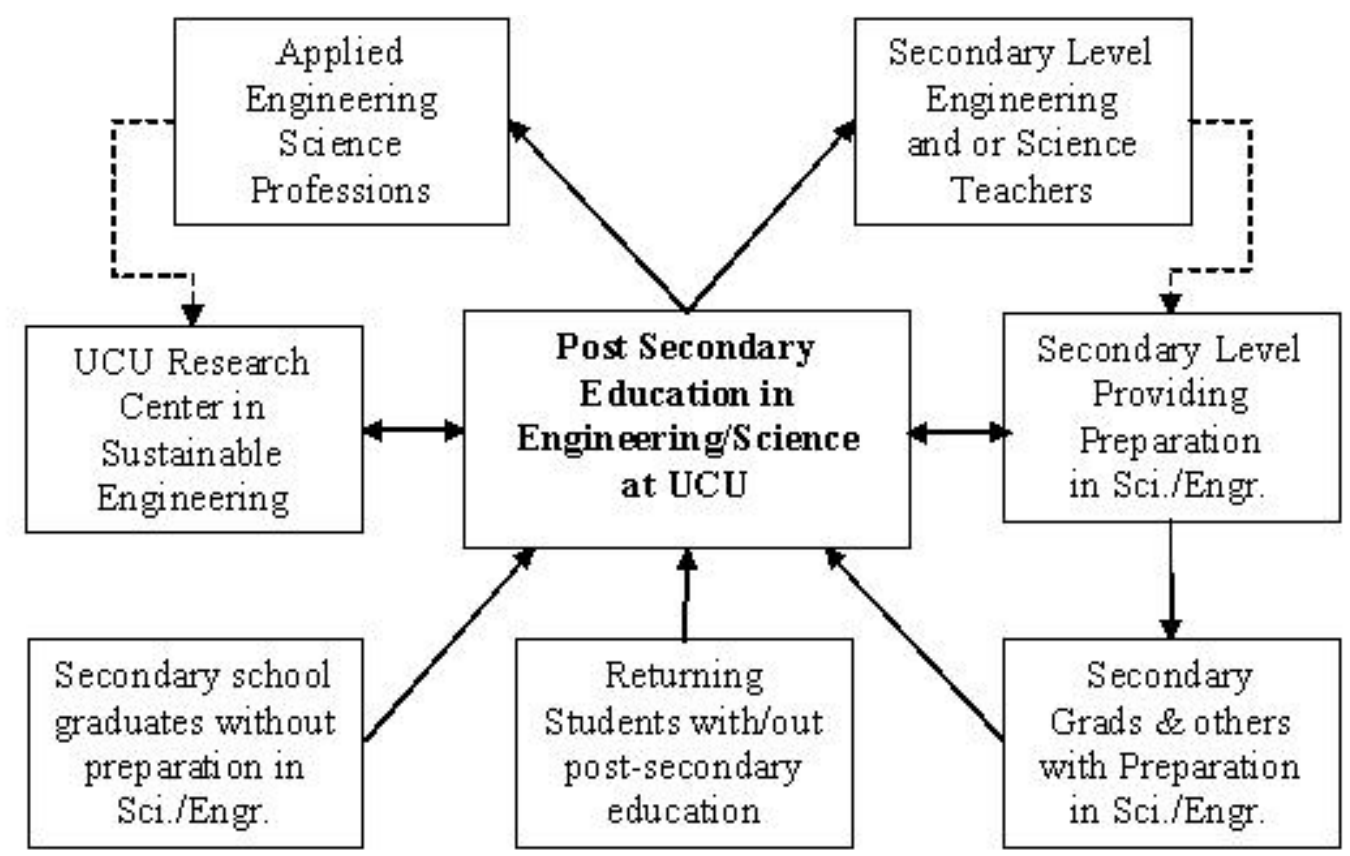

Figure 1 Process Model

As the figure shows, there are students being trained at the pre-college and college levels. These students will have (assuming completion/graduation) the ability to enter applied science or engineering professions or they will be able to teach at the secondary level. Also, we will have a source of technically trained individuals to participate in the afore mentioned technical projects.

Over the past 4 years our involvement technologically has been significant. Using the performance process model we can anticipate the Ugandan stakeholders getting more involved over the next 5 years reducing our commitment.

Proceedings of the 2003 American Society for Engineering Education Annual Conference \& Exposition Copyright (C) 2003, American Society for Engineering Education 
Figure 2 shows the levels of involvement in the projects over the past 5 years. It shows the estimates of active participation of our team and the Ugandan stakeholders in the projects.

Since each project integrates with people and resources at the local sites, there is heavy involvement on both sides. It was our original goal from the beginning to transition our technical projects to the Ugandans. In so doing, we recognized the need for engineering and science training. Now, our stakeholders also understand and desire this. Our involvement is not as crucial in terms of time commitments next year or over the next 5 years as it is now. We planned our level of involvement to diminish over time. This necessitated the need to train Ugandan stakeholders. The training they receive and will receive in the curriculum is relevant to sustaining these technical projects.

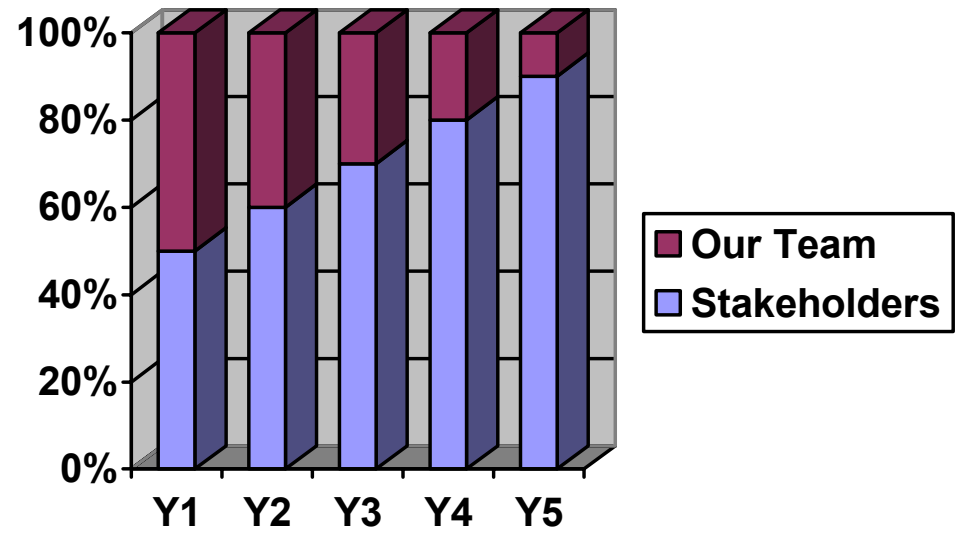

Figure 2 of Stakeholders and Our Involvement time/materials

Therefore, the diminishing participation on our part promotes sustainability of the current projects beyond our planned involvement.

In the beginning of the work, each side had investments of time and materials. It was about a 5050 share. As the various projects have progressed, our involvement has diminished. With each year, every part of the work has more involvement by the Ugandan people and less of our input. This of course is easy to understand whenever you consider the coffee farm, for example. In the beginning we provided substantial support in terms of purchasing the initial plants and property, teaching on how to care for the farm etc. Now it is the stakeholders in Uganda who do the work of actually planting, harvesting etc. 


\section{Conclusion}

Since 1999 we have been heavily invested in focused areas. Throughout our work, we have seen and heard from our project participants of the need for more people trained in the area of science and engineering. Following the same methodology that we utilized in the other successful projects, we have proposed an educational project in cooperation with Uganda Christian University to meet the technology needs in Uganda. There will be measurements regarding the progress at regular intervals. This will allow us the ability to modify the course content or even add things as the project progresses. The educational project is scalable and flexible. It can be changed effectively as it grows without compromising the goals. Also, the educational project accomplishes two things. First it trains engineers and scientists. Secondly, the proposed curriculum accommodates university students who need training to be teachers of science and engineering fundamentals for secondary schools.

Our technical work has provided the foundation for this technical education project. This project is also sustainable though the same generous support our projects have received in the last five years. It is well underway with support from leadership in the large dioceses of Bunyoro-Kitara, the Uganda Christian University, and the stakeholders of our existing projects.

Bibliography

1. Library of Congress / Federal Research Division / Country Studies / Area Handbook Series / Uganda by the Federal Research Division of the Library of Congress, Available at http://memory.loc.gov/frd/cs/ugtoc.html

2."Fostering Inventiveness in Engineering Education-An International Perspective",

Z. Prusak, 2002.Proceedings of the 2002 American Society for Engineering Education Annual Conference and Exposition,

3. Background paper on indigenous knowledge for sustainable development: towards a national strategy and framework of Action for Uganda prepared by Dr. Z.M. Nyiira, Dr. C.F. Mugoya and J.N. Muwanga. A paper presented at the workshops on Development of a National Strategy Framework and Action Plan for the Sustainable Application of Indigenous Knowledge, 8 - 9 December 1999 Kampala.

4. Strategies for Appropriate Technology Development in Food Wector; a Case for Uganda J.N. Muwanga. Paper presented at the Workshop on African Food Processing Technologies for Commercialization, 24-29 June 1996, Nairobi, and Kenya

5. Uganda's Initiatives to Enhancing Science and Technology Capacity: Policy and Practice by Dr. Z.M. Nyiira. Keynote paper presented at the Forum on Science in Africa on the Challenges of Capacity Building, 8-13 May 1994 Washington, USA.

Proceedings of the 2003 American Society for Engineering Education Annual Conference \& Exposition Copyright $\left({ }^{\circ}\right.$ 2003, American Society for Engineering Education 
6. Participation and Social Assessment Guidebook on Tools and Techniques", prepared by Jennifer RietbergenMcCracken \& Deepa Narayan: ISBN NO. 082-1341863 (A copy of this guidebook is available at the World Bank Library); Website: http://www.worldbank.org

7. Article published in the Pittsburgh Post-Gazette newspaper, Pittsburgh, PA, Ervin Dyer, November 15, 2001,

8. Report of the Proceedings of the Consultative Workshop on Indigenous Knowledge (IK) for Development Initiative, 10 August 1999, Conference Hall, Faculty of Forestry and Nature Conservation, Makerere University by Mrs. J.N. Muwanga.

9. Report of the Proceedings of the Workshop on Development of a National Strategy Framework and Action Plan for the Sustainable Application of Indigenous Knowledge, 8 - 9 December 1999, Kampala by Mr. I.N. Barugahara and Mrs. J.N. Muwanga

10. National Priorities in Science and Technology in Uganda by Mrs. J.N. Muwanga at the Regional Meeting of the Southern and Southern East Africa Commonwealth Science Council Member Countries, 13 October 1997, Pretoria, South Africa.

11. The National Science and Technology Policy: Challenges of Science, Engineering and Technology for National Development by Dr. Z.M. Nyiira. Presented at the Inaugural National Technology Conference organized by the Uganda Institution of Professional Engineers, 14-16 February 1996, KICC, Kampala, Uganda

12. Angelo, T. A. and K. P. Cross, Classroom Assessment Techniques: A Handbook for College Teachers, 2nd ed., Jossey-Bass, San Francisco, CA 1993.

13. Maillie, J. B., William R. Park, Strategic Analysis for Venture Evaluations: The Save Approach to Business Decisions, Van Nostrand Reinhold; NY June 1997.

FRANK T. DUDA, JR.

Dr. Frank T. Duda, Jr., is Professor of Electrical Engineering at Grove City College in Grove City, Pennsylvania. Frank received his B.S.E.E., M.S.E.E. and Ph. D from the University of Pittsburgh. In addition to teaching, Frank is a practicing licensed Professional Engineer in the state of Pennsylvania and does research for The National Institute for Occupational Safety and Health (NIOSH). Dr. Duda has traveled to Uganda several times to promote the development of educational projects in the area of engineering education.

\section{DOUGLAS LAUFFER}

Rev. Douglas Lauffer is Associate Professor of Computer Information Systems/Telecommunications at Community College Beaver County in Monaca, Pennsylvania. Doug received his Master of Science in Telecommunications (MST) from the University of Pittsburgh. He is a member of the clergy staff at Christ Church at Grove Farm in Sewickley, Pennsylvania. Rev. Lauffer is on the board of the Uganda Partners, a development organization promoting UCU internationally. He has also worked with Dr. Duda in Uganda Africa.

Proceedings of the 2003 American Society for Engineering Education Annual Conference \& Exposition Copyright $\left({ }^{\circ}\right.$ 2003, American Society for Engineering Education 